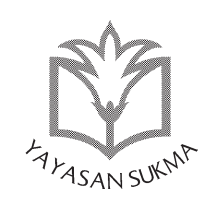

SUKMA: JURNAL PENDIDIKAN

ISSN: 2548-5105 (p), 2597-9590 (e)

Volume 2 Issue 2, Jul-Dec 2018, pp. 287-310

https://doi.org/10.32533/02207.2018

www.jurnalsukma.org

\title{
PENDIDIKAN POLITIK DI ERA DISRUPSI
}

\section{Khoiruddin Bashori}

Universitas Ahmad Dahlan Yogyakarta, Indonesia

email: khoiruddinbashori@gmail.com

\section{Abstrak}

Era disrupsi adalah masa ketika perubahan terjadi sedemikian tidak terduga, mendasar dan hampir dalam semua aspek kehidupan. Tatatan baru hadir menggantikan tatanan lama yang sudah tidak sesuai dengan tuntutan zaman. Dalam hal politik, disrupsi akan mendorong terjadinya digitalisasi sistem politik. Munculnya inovasi aplikasi teknologi digital akan menginspirasi lahirnya aplikasi sejenis di bidang politik. Tidak lama lagi, hingar bingar kampanye pengerahan massa, akan diganti dengan edukasi via berbagai media soal, yang tidak saja lebih murah akan tetapi juga memiliki daya jangkau audien yang jauh lebih luas dan merata. Paper ini ingin mengungkapkan perlunya pemahaman kita tentang politik di era disrupsi, dan bagaimana meng- 
hadapi fenomena ini dengan lebih menekankan pada perlunya pendidikan politik yang lebih dapat menyesuaikan dengan kondisi saat ini.

Keywords: disrupsi, literasi politik, digitalisasi politik, pendidikan politik, agen sosialisasi politik

\section{A. Pendahuluan}

Era disrupsi adalah masa ketika perubahan terjadi sedemikian tidak terduga, mendasar dan hampir dalam semua aspek kehidupan. Dunia hari ini sedang menghadapi fenomena di mana pergerakan dunia tidak lagi berjalan linear. Tatatan baru hadir menggantikan tatanan lama yang sudah tidak sesuai dengan tuntutan zaman. Disrupsi menginisiasi lahirnya model interaksi baru yang lebih inovatif dan masif. Cakupan perubahannya luas mulai dari dunia usaha, perbankan, transportasi, sosial kemasyarakatan, pendidikan hingga politik. Oleh sebab itu era ini melahirkan dua pilihan penting: berubah atau punah.

Tidak diragukan lagi, disrupsi akan mendorong terjadinya digitalisasi sistem politik. Munculnya inovasi aplikasi teknologi digital akan menginspirasi lahirnya aplikasi sejenis di bidang politik. Hingar bingar kampanye pengerahan massa, akan diganti dengan edukasi via berbagai media soal, yang tidak saja lebih murah akan tetapi juga memiliki daya jangkau audien yang jauh lebih luas dan merata. Kini orang bahkan dapat memanfaatkan MO0C, singkatan dari Massive Open Online Course serta AI (Artificial Intelligence) untuk kepentingan pendidikan politik. MOOC adalah inovasi pembelajaran daringyang dirancang terbuka, dapat saling berbagi dan saling terhubung atau berjejaring satu sama lain. Adapun AI adalah mesin kecerdasan buatan yang dirancang untuk melakukan pekerjaan yang spesifik dalam membantu keseharian manusia. Dalam pendidikan politik, AI akan membantu pendidikan yang bersifat lebih individual, personal. Sebab, AI mampu melakukan pencarian informasi politik yang diinginkan sekaligus menyajikannya dengan cepat, akurat, dan interaktif. 
Bagi mereka yang belum siap, era ini menghadirkan banyak kejutan yang mengagetkan, namun pada saat yang sama juga memberikan banyak peluang. Kini pengetahuan, termasuk tentang dinamika politik lokal, nasional, regional maupun internasional menjadi sedemikian murah dan terbuka. Disrupsi menandai dimulainya demokratisasi pengetahuan yang menciptakan kesempatan bagi siapapun untuk dapat memanfaatkan dunia teknologi secara lebih produktif. Tidak terkecuali pemanfaatan kemajuan teknologi digital untuk pendidikan politik. Karena sejatinya pendidikan politik dimaksudkan sebagai upaya yang dilakukan agar masyarakat lebih dapat memahami sistem politik yang berlaku, meningkatkan kesadaran politik dan partisipasi politik masyarakat.

Sejak era reformasi begitu banyak pihak berharap dengan iklim demokrasi yang lebih berkualitas. Korupsi, Kolusi dan Nepotisme yang menjadi penyakit orde sebelumnya tidak lagi menjadi momok. Rupanya jauh panggang dari api, harapan tinggal harapan. KKN justru semakin sulit diatasi. Semangat otonomi dan desentralisasi yang dimaksudkan untuk menghilangkan KKN di tingkat pusat, namun yang terjadi kemudian justru semacam menindahkan persoalan KKN ke daerah. Ketika otoritas keuangan banyak di berikan pada pemerintah daerah, adagium power tends to corrupt benar-benar menjadi kenyataan. Banyak kasus-kasus KKN yang mencuat ke publik kini pelakunya adalah orang-orang daerah.

Sementara pengamat menganggap saat ini Indonesia masih berada pada tahap transisi demokrasi. Masih diperlukan upaya-upaya yang lebih sistematis dan terstruktur dari seluruh pemangku kepentingan untuk bersama mewujudkan Indonesia yang lebih demokratis dan berkeadaban. Menurut Bakri, dkk. (2012) terdapat tiga sumbatan yang terjadi yang memerlukan penyelesaian serius dalam praktek demokasi negeri ini. Pertama, terjadi sumbatan dalam kekuasaan eksekutif. Performa kabinet masih mandul dan terbebani politik akomodasi dalam menjalankan perannya. Apa yang menjadi prioritas pemerintah adalah koalisi yang terakomodasikan pada pembagian pos-pos 
kekuasaan, dan bukan zaken kabinet yang sesuai dengan kapasitas untuk mempersembahkan kinerja terbaik untuk rakyat.

Kedua, sumbatan dalam kekuasaan legislatif. Terjadi legislative heavy, yaitu dominannya fungsi-fungsi legislatif dalam mengkontrol anggaran dan pembuatan kebijakan. Sangat terasa, dominasi di sini lebih memperhitungkan kepentingan diri dan kelompok, bersifat transaksional dan menjadi bagian dari manajemen konflik. Ketiga, sumbatan di bidang hukum. Masih kuatnya akar korupsi tertanam di lembaga-lembaga pemerintahan dari legislatif, yudikatif hingga eksekutif menjadikan penegakan hukum sangat lemah (Bakri et al. 2012).

Paper ini secara sederhana ingin mengungkapkan perlunya pemahaman kita tentang politik di era disrupsi, dan bagaimana menghadapi fenomena ini dengan lebih menekankan pada perlunya pendidikan politik yang lebih dapat menyesuaikan dengan kondisi saat ini.

\section{B. Literasi Politik}

Literasi politik merupakan aspek penting dalam konsolidasi demokrasi. Kurangnya pemahaman tentang isu-isu politik dan kegiatan politik tidak jarang menyebabkan masyarakat apatis terhadap berbagai proses demokrasi dan dinamika politik pemerintahan di sekitarnya. Pada kenyatannya fluktuasi tingkat partisipasi politik sering berkiatan erat dengan rendahnya literasi politik. Dalam konteks ini literasi politik dipahami sebagai pemahaman praktis tentang konsep-konsep yang diambil dari kehidupan sehari-hari dan bahasa, merupakan upaya memahami seputar isu politik, keyakinan para kontestan, bagaimana kecenderungan mereka mempengaruhi diri sendiri dan orang lain. Dengan kata lain literasi politik merupakan senyawa dari pengetahuan, keterampilan dan sikap mengenai politik (Bakri et al. 2012).

Muatan pokok literasi politik dapat berupa: Partisipasi politik dan Pemahaman kritis warga atas hal-hal pokok terkait politik. Partisipasi politik warga dapat dibedakan atas beberapa 
kategori: 1) Dilihat dari kegiatannya, partisipasi politik aktif dan pasif. Dikatakan aktif apabila masyarakat tersebut terlibat aktif dalam perumusan kebijakan pemerintah. Sementara partisipasi politik pasif merupakan kegiatan yang mencerminkan ketaatan terhadap keputusan pemerintah 2) Dilihat dari tingkatannya, dibedakan menjadi apatis, spektator dan gladiator. Apatis artinya tidak menaruh perhatian sama sekali terhadap kegiatan politik dan bersikap masa bodoh. Spektator adalah warga yang bersangkutan terlibat atau ikut memilih dalam Pemilu. Sedangkan gladiator berpartisipasi secara aktif dalam proses politik 3) Partisipasi dibedakan atas jumlah, ada yang bersifat kolektif dan lainnya individual 4) Dilihat dari tinggi rendahnya partisipasi dapat dibedakan menjadi partisipasi aktif; partisipasi apatis (ada kepercayaan kepada politik namun kurang percaya pada system yang ada); partisipasi militan radikal (kepercayaan kepada politik tinggi namun percaya kepada system rendah); partisipasi tidak aktif (kesadaran politik rendah, tetapi percaya kepada system politik sangat tinggi) (Bakri et al. 2012).

Adapun Pemahaman kritis warga atas hal-hal pokok terkait politik menyangkut pemahaman warga mengenai politik itu sendiri dan aspek aspek yang berhubungan dengan konsep negara, kekuasaan, pengambilan keputusan, kebijakan umum, pembagian dan alokasi yang merupakan hal pokok yang harus dipahami oleh warga untuk berpartisipasi aktif dalam politik. Rendahnya pemahaman kritis warga negara terhadap isu-isu politik kontemporer seringkali diikuti oleh menurunnya partisipasi publik dalam proses-proses politik. Meskipun dalam kasus lain terdapat fenomena yang sebaliknya. Di negera-negara maju, dengan konsolidasi demokasi yang sudah relatif mapan, seperti yang terjadi di Amarika Serikat dan negara-negara yang tergabung dalam Uni Erapa terdapat realitas yang sebaliknya. Meskipun pemahaman kritis warga tinggi namun partisipasi politik dalam pemilihan umum ternyata tidak cukup tinggi.

Pendekatan dalam meningkatkan literasi politik warga dikemukakan Bakri et al. (2012) sebagai berikut: (1) kebutuhan terhadap informasi politik, terkait dengan informasi apa 
yang dibutuhkan untuk mengetahui secara jelas informasi tentang partai politik dan kandidat (pendidikan formal, karier, keluarga, visi misi, dll), (2) menetapkan strategi pencarian, merupakan strategi investigasi terhadap seluruh proses politik misalnya sumber dana kampanye, tim sukses, pelanggaraan prosedur kampanye, dll., (3) gerakan mengkomunikasikan informasi, terkait dengan peran media dalam proses publikasi. Ada baiknya jika media membuat asosiasi yang kuat untuk mengawasi pemilu sekaligus sebagai kekuatan penyeimbang. Meliput janji kampanye merupakan salah satu langkah strategis agar di kemudian hari terdapat bukti otentik tentang janji politik yang pernah disampaikan, (4) mengevaluasi produk dari proses akhir politik, terkait dengan evaluasi menyeluruh di setiap tingkatan kampanye Pemilu/Pemilu Kada. Masyarakat punya hak untuk mengevaluasi dan merekomendasikan apakah seorang kandidat layak atau tidak.

Literasi politik dapat ditingkatkan dengan sosialisasi politik yang benar. Sosialisasi politik memiliki dua kata, yaitu sosialisasi dan politik. Dalam Kamus Besar Bahasa Indonesia, sosialisasi memiliki arti antara lain upaya memasyarakatkan sesuatu sehingga menjadi dikenal, dipahami dan dihayati oleh masyarakat. Sedangkan politik ialah pengetahuan mengenai ketatanegaraan atau kenegaraan, seperti tentang sistem pemerintahan dan dasar pemerintahan atau diartikan juga dengan segala urusan dan tindakan yang meliputi kebijakan, siasat, dan sebagainya mengenai pemerintahan negara atau terhadap negara lain. Secara lebih luas, politik juga dapat dimaknai sebagai kebijaksanaan atau cara bertindak dalam menghadapi atau menangani suatu masalah. Dengan demikian sosialisasi politik dapat dipahami sebagai suatu upaya atas pengetahuan mengenai ketatanegaraan atau kenegaraan dapat dikenal, dipahami dan dihayati oleh masyarakat. Pendek kata sosialisasi politik tidak lain adalah pembentukan sikap dan orientasi politik anggota masyarakat.

Pelaksanaan sosialisasi politik sangat ditentukan oleh interaksi pengalaman dan kepribadian seseorang, lingkungan sosial, 
kultur serta keadaan ekonomi di mana mereka tinggal. Upaya memasyarakatkan politik ini memerlukan waktu yang cukup lama, karena untuk membentuk pandangan politik perlu mempengaruhi individu-individu sehingga dapat membentuk tingkah laku politik sesuai dengan yang diinginkan. Hal ini dimungkinkan oleh karena pengetahuan, nilai serta sikap yang diperoleh seseorang akan membentuk suatu persepsi politik. Pandangan dan juga tingkah laku politik seseorang akan berkembang secara berangsur-angsur. Namun, tidak sedikit orang yang apatis terhadap politik, selain karena upaya sosialisasi yang salah maupun karena melihat realitas politik yang sangat tidak memenuhi ekspektasi, bahkan ada juga yang mengaitkan dengan pandangan agama, yang kemudian meyakini bahwa politik itu kotor.

\section{Agen Sosialisasi Politik}

Menurut Wasburn dan Covert (2017) sosialisasi politik dapat dilakukan mulai dari lingkungan keluarga, sekolah, tempat-tempat ibadah, tempat kerja, dalam kelompok sosial dan oleh media. Masing- masing baik sendiri-sendiri atau bersamasama memiliki peran yang tidak kecil dalam membetuk sikap dan perilaku politik warga negara. Kajian yang lebih mendalam mengenai agen-agen sosialisasi politik ini akan memperjelas kontribusi masing-masing dalam dinamika politik warga.

\section{Keluarga}

Keluarga yang dikatakan sebagai organisasi terkecil dalam sebuah tatanan masyarakat memiliki keragaman berfikir dan kecenderungan secara politik. Hal ini terjadi disebabkan oleh faktor yang berbeda-beda pula dalam setiap keluarga. Nilai-nilai yang dianut pun juga mengalami perubahan, seiring dengan pergeseran tantangan kehidupan yang dihadapi keluarga. Misalnya value lama sebuah keluarga yang di dalamnya hanya didominasi oleh kepala keluarga, kini sudah mulai bergeser. Keluarga modern cenderung memiliki pola hubungan yang lebih demokratis, dengan peran masing-masing yang relatif setara. Saat ini banyak 


\section{Khoiruddin Bashori}

keluarga modern yang telah bertransformasi, dan ini sangat mendukung internalisasi nilai-nilai demokrasi sejak dini.

Daya tarik kerabat merupakan tema penting dalam kajian sosialisasi politik. Meski keluarga memiliki otoritas terkuat bagi pembentukan opini dan sikap politik anggotanya, akan tetapi berdasarkan berbagai penelitian ditemukan bahwa pada kenyatannya sikap politik anak tidak selalu sejajar dengan sikap politik orangtuanya. Hal ini misalnya terjadi pada kasus ketika sikap politik orangtua berbeda dengan sikap politik teman sebaya anak. Bagi anak keadaan demikian menyebabkan kebingungan apakah akan mengikuti sikap orangtua atau lebih memperhatikan aspirasi teman sebayanya. Keadaan demikian tidak jarang melahirkan sikap golput pada anak, sebagai upaya untuk menghindari berbedaan pilihan politik. Pada akhirnya sikap politik anak lebih ditentukan oleh seberapa tertarik, seberapa dekat, anak dengan orangtua dan sahabat karibnya. Jika anak lebih dekat dengan orangtua, maka mereka cenderung mengikuti polihan orangtua, sebaliknya manakala anak merasa lebih dekat dengan sahabat karibnya, pilihan anak akan menyesuaikan dengan pilihan politik teman-teman dekatnya.

Di samping itu, kesamaan pendapat kedua orangtua juga menjadi variabel penting yang akan menentukan bagaimana sikap politik anak ketika dihadapkan pada persoalan-persoalan kemasyarakatan kontemporer. Kajian psikologi menunjukkan secara umum, pengaruh keluarga cenderung lebih kuat ketika sudut pandang anggota adalah homogen. Sebagaimana dicatat, individu dengan orang tua yang mendukung pihak yang berbeda cenderung tidak memiliki preferensi partai yang kuat daripada mereka yang berasal dari keluarga di mana kedua orang tua mendukung pihak yang sama. Ini berarti kesamaan sikap dan pilihan politik kedua orangtua memiliki pengaruh yang lebih kuat pada sikap dan polihan politik anak bila dibandingkan dengan anak dengan orangtua yang tidak memiliki kesamaan sikap politik. Pada gilirannya, identifikasi pihak yang lemah cenderung dikaitkan secara negatif dengan keterlibatan politik. Dengan demikian kemampuan orang tua untuk menanamkan orientasi partisan 
Pendidikan Politik di Era Disrupsi

dipengaruhi oleh kesepakatan orang tua. Sejauh mana orang tu a setuju satu sama lain tampaknya memiliki peran lebih penting daripada factor lain seperti demografi wilayah atau karakteristik pribadi seperti ras dan jenis kelamin.

Telah lama diketahui keluarga dengan ikatan emosional yang kuat, ditambah lagi orang tua sering mendiskusikan urusan kemasyarakatan dengan anak-anak cenderung memiliki pengaruh lebih kuat dalam perkembangan politik anak-anak. Namun, manakala keluarga tidak membangun kesetiaan partisan yang jelas, anak-anak cenderung baru mulai terlibat secara politis ketika mereka mencapai kedewasaan. Pada keluarga dengan tingkat kohesivitas yang tinggi cenderung mencoba menyelesaikan pertentangan politik yang muncul di antara mereka melalui diskusi. Keadaan ini yang dapat membuat diskusi politik menjadi lebih menonjol dalam keluarga. Ketika politik sudah menjadi menu diskusi harian bagi anak-anak, selanjutnya mereka dengan lebih mudah dapat berpartisipasi dalam kehidupan politik. Percakapan politik tidak selalu dimulai dari orang tua. Diskusi yang diprakarsai oleh anak-anak, mungkin menanggapi kurikulum kewarganegaraan, kampanye yang sedang berlangsung atau acara berita utama lainnya, dapat pula merangsang orang tua untuk lebih memperhatikan masalah-masalah politik.

Anak-anak mengamati dan cenderung menyerap antusiasme politik orang tua di rumah. Sudah menjadi rahasia umum, warga yang terlibat dalam aktivitas politik cenderung menjadi produk dari keluarga yang tertarik secara politis. Keluarga-keluarga seperti itu, di mana ada banyak diskusi politik, tidak hanya memancarkan informasi politik tetapi juga memunculkan identifikasi partai yang positif dan menanamkan rasa tertarik secara politis. Pada usianya yang lebih dini, anak dari keluarga yang menunjukkan minat politik tinggi akan mendapatkan atmosfer politik yang lebih intens. Sementara itu bagi orang dewasa, mendapatkan informasi politik, memiliki identifikasi partai, dan memiliki kayakinan bahwa seseorang dapat memiliki dampak penting pada urusan politik didapat melalui pencarian diri. Kesadaran pribadilah yang lebih mendorong partisipasi dalam 
kehidupan politik.

Pada kenyatannya tidak semua keluarga adalah keluarga utuh, ada orangtua tunggal dalam proporsi yang cukup tinggi dalam sejumlah populasi. Dalam data kasus yang dirilis oleh U.S. Census Bureau pada tahun 2012 misalnya ditemukan bahwa di Amerika mayoritas yang menjadi single-parentadalah perempuan (Covert \& Wasburn 2017). Hal ini disebabkan karena perceraian atau dikarenakan pasangan yang meninggal. Apa hubungannya dengan pendidikan politik? Ketika mayoritas perempuan yang mendapat peran sebagai single-parent, maka dapat dipahami bahwa perempuanlah yang akan menjalankan peran sebagai sumber pengetahuan politik bagi keluarganya. Dengan demikian pengetahuan sang ibu dalam bidang politik yang akan dijadikan sebagai rujukan utama oleh anak dalam perkembangnya menuju kedewasaan. Sekalipun saat mereka dewasa tidak tertutup kemungkinan untuk memperkuat pemaham atau bahkan mengembangkan pandangan politik yang berbeda. Namun peran ibu sebagai orangtua tunggal tetap sangat penting dalam pendidikan politik keluarga.

Covert dan Wasburn (2017) mengingatkan, secara kultural dipercaya bahwa laki-laki lebih tertarik terhadap politik dibandingkan perempuan. Bahkan seorang laki-laki lebih aktif dalam kiprah perpolitikan dibanding perempuan. Kenyataan demikian tentu akan menjadi persoalan pada keluarga dengan ibu sebagai orangtua tunggal. Ketidak tertarikan ibu terhadap isu-isu politik kontemporer, dan minimnya keterliban dalam berbagai aktivitas politik dapat menyebabnya kecilnya sumber informasi politik yang dapat diperoleh anak dari keluarga. Oleh karena itu, sosialisasi politik sudah seharusnya diprioritaskan pada konstituen perempuan, agar dapat menjadi "narasumber" politik yang memadai bagi anak-anaknya. Ketersediaan informasi politik bagi ibu dan meningkatnya minat politik perempuan akan sangat mempengaruhi partisipasi politik anak bangsa.

Sosialisasi politik dalam keluarga bukan sekadar proses transformasi dua generasi, lebih tepatnya tiga generasi. Orangtua 
merupakan agen sosialisi politik yang berada di tengah. Pada awalnya orangtua memperoleh agenda dan sikap-sikap politik dari orang tua dan kemudian meneruskannya kepada generasi anaknya, meskipun dalam perjalanan sering pula diubah oleh pengalaman politik pribadi mereka sendiri. Data menunjukkan, transmisi identifikasi partai politik melemah dari generasi pertama hingga ketiga. Sudah menjadi ketentuan zaman, sikap sosial politik cenderung berbeda antar generasi seiring dengan berlalunya waktu. Kajian psikologi politik menginformasikan bagaimana proses sosialisasi politik akan berbeda jika orang tua sebagai "generasi tengah" tidak hadir. Hari ini, tidak sedikit anak-anak yang dibesarkan oleh kakek dan nenek, bukan oleh orangtua. Ini berarti tugas pendidikan politik langsung diambil alih oleh generasi pertama, karena ketiadaan generasi kedua. Ketika kakek-nenek mempertahankan kehadiran sehari-harinya dalam kehidupan cucu-cucu, maka cucu cenderung memperoleh beberapa nilai penting dan keyakinan politik dari kakek-nenek.

Ras telah lama menjadi variabel yang dipertimbangkan dalam penelitian sosialisasi politik. Namun, pertanyaan tentang bagaimana orangtua dengan identitas rasialyang berbeda melakukan sosialitasi politik sering diabaikan. Padahal kini semakin banyak keluarga dengan orangtua yang berbeda suku dan bangsanya. Secara historis, individu dengan orangtua berbeda suku sering terpaksa harus mengidentifikasi hanya pada satu latar belakang, biasanya identitas ayah. Struktur pengalaman sosial mereka berinteraksi dengan orangtua dengan suku-bangsa yang berbeda membentuk persepsi politik yang beragam. Oleh karena itu salah satu model pembentukan identitas rasial menjelaskan bahwa individu dengan orangtua berbeda suku memiliki hak untuk menentukan pilihan. Bagaimana mereka ini memilih bergantung pada identifikasi rasial yang mereka miliki. Pada kenyataannya pilihan politik memang tidak selalu secara konsisten bergantung pada keterikatan kelompok ras. Sebaliknya, mereka dapat saja membuat keputusan strategis yang dianggap lebih menguntungkan dalam situasi politik tertentu.

Dalam kehidupan modern yang semakin rumit dan komplek, 
tidak sedikit keluarga yang kini memilih homeschooling, sebagai pilihan alternatif pendidikan bagi anak. Alasan memilih home schooling antara lain ingin menanamkan nilai agama dan moral (30\%), memberikan nilai lebih untuk peduli lingkungan, memberikan nilai aman yang lebih ketat terhadap bahaya obat-obatan terlarang dan tekanan dari teman sebaya (21\%), kekecewaan terhadap tuntutan akademik (17\%) dan faktor lainnya seperti pertimbangan keluarga, keuangan, jarak ke sekolah, kesehatan anak dan atau anak berkebutuhan khusus (Covert \& Wasburn 2017). Apapun alasannya, sekolah jenis ini, yang dilakukan di rumah masing-masing anak, akan sangat mungkin menyebabkan anak tidak memiliki interaksi yang kuat dengan lingkungan. Anak lebih banyak fokus terhadap pelajaran dan tidak begitu memperhatikan lingkungan sosialnya. Meskipun anak home schooling belum tentu buruk komunikasinya dengan masyarakat umum, namun setidaknya pengalaman empiris anak dalam menghadapi banyak orang akan berkurang. Ada anggapan home schooling dianggap metode yang tepat untuk merawat rasa sosial dan pemahaman politik yang konservatif. Tentunya orang tua yang menolak sekolah umum untuk anak-anak mereka dan memilih memberikan pendidikan sendiri di rumah memiliki pengaruh yang cukup besar sebagai agen sosialisasi politik. Pendidikan di rumuah ini cenderung mencerminkan perspektif ideologis. Anak-anak yang belajar di rumah memiliki kontak lebih sedikit dengan guru dan teman sebaya yang pandangan sosial dan politiknya mungkin berbeda dari orang tua. Dikhawatirkan anak kemudian mengalami kesulitan beradaptasi terhadap dinamika sosial-politik di lingkungannya.

\section{Sekolah}

Studi menunjukkan bahwa, pada awal usia, sekolah cenderung mengembangkan rasa kesetiaan nasional yang kuat di dalam diri anak - perasaan bahwa menjadi orang Indonesia lebih baik daripada menjadi warga negara lain. Di kelas awal, anakanak mengembangkan rasa "kita" dalam hubungannya dengan 
negara sendiri dan rasa "mereka" terkait dengan warga negara lain. Pada tahun-tahun awal sekolah, sebagian besar anak-anak datang dengan mengidealkan otoritas politik yang sudah mapan. Pada saat anak-anak berusia tujuh atau delapan tahun, mereka menjadi sadar bahwa ada otoritas di luar keluarga yang menuntut dukungan, kepatuhan, dan rasa hormat. Awalnya, karena keterbatasan kognitif mereka, anak-anak mengkonsepkan otoritas ini dalam hal orang-orang konkret seperti presiden dan polisi. Seiring dengan bertambahnya usia, anak mulai pahan dengan konsep-konsep abstrak seperti pemerintah. Ketika anak-anak tumbuh dewasa, mereka menjadi kurang idealis. Tokoh-tokoh politik dipandang kurang heroik dan murah hati, dan mulai memahami beberapa ketidaksetaraan dalam hokum.

Demikianlah, selain keluarga, sekolah adalah institusi strategis yang dapat melakukan pendidikan politik warga negara. Sekolah diharapkan dapat mengembangkan model-model pembelajaran yang dapat memungkinkan idealisme itu menjadi kenyataan. Biasanya ada dua pendekatan yang digunakan, yaitu pendidikan kewarganegaraan (civic) dan model "big issues". Bila pendidikan kewarganegaraan menekankan literasi politik sebagai produk, dengan melakukan transmisi pengetahuan politik faktual menggunakan metode pembelajaran didaktik, model kedua menekan pendidikan literasi politik sebagai proses. Model big issues dilakukan dengan memperkenalkan anak dengan isu-isu politik penting melalui berbagai diskusi dan debat-debat politik. Sudah barang tentu keduanya memiliki kelebihan dan kekurangannya masing-masing (Davies \& Hogarth 2004).

Di antara kelemahan yang menonjol dari kedua pendekatan ini misalnya meskipun para guru mungkin ingin menggunakan isu-isu kontroversial sebagai studi kasus untuk mengembangkan pemahaman yang lebih luas, transfer yang diharapkan tidak muncul secara eksplisit dan sering tidak terjadi. Siswa pada akhirnya seperti dibiarkan memiliki pengetahuan mendalam tentang satu masalah tertentu yang dipilihnya sendiri. Oleh karena masalah-masalah tersebut pada umumnya dipilih oleh media dan bukan oleh pendidik, siswa tidak dapat memperoleh 
pengenalan yang sistematis terhadap ide-ide politik sebagaimana yang diharapkan.

Pendekatan alternatif yang disarankan oleh Davies dan Hogarth (2004) adalah model 'wacana publik' (public discourse). Model ini berusaha memasukkan siswa ke dalam bahasa, konsep, bentuk-bentuk argumen dan keterampilan yang diperlukan untuk berpikir dan berbicara tentang kehidupan dari sudut pandang politik, menekankan baik proses maupun produk. Pengetahuan faktual memang penting, tetapi tetap harus terkait dengan aspekaspek lain yang penting secara sentral bagi literasi politik siswa. Oleh karenanya pengembangan kurikulum dilakukan dengan identifikasi konsep-konsep kunci yang menyusun pemikiran tentang bidang-bidang tertentu dalam kehidupan sosial-politik. Penelitian terbaru menunjukkan bahwa tekad untuk membuat siswa terlibat dalam perdebatan aktif umumnya dianggap sangat tepat untuk pengembangn konsep-konsep penting, seperti demokrasi dan otokrasi, kerjasama dan konflik, kesetaraan dan keragaman. Sekolah yang memodelkan praktik demokrasi paling efektif dalam mempromosikan pengetahuan dan keterlibatan politik sipil.

Jenis-jenis pemahaman yang perlu dimiliki seseorang agar dapat berpikir dan berbicara tentang kehidupan kontemporer dari sudut pandang politik perlu disiapkan dengan baik, sebelum sekolah membangun kurikulum baru yang dapat menfasilitasi pendidikan politik warga. Sejumlah kategori dapat diidentifikasi terkait dengan berbagai aspek kehidupan politik, misalnya, 'cita-cita', 'lembaga', 'ideologi', 'sistem', dan 'partisipasi' politik serta konsep politik umum yang memiliki implikasi yang lebih luas, seperti , 'kekuatan', 'otoritas', 'perwakilan', 'pemerintah', dll. Ketepatan penentuan jenis-jenis pemahaman yang diperlukan siswa agar dapat berlaku sebagai warga negara yang baik, akan memudahkan pemangku kepentingan pendidikan dalam pemilihan metodologi pembelajaran yang dianggap cocok untuk dapat mewujudkannya dalam kenyataan.

Pada prakteknya, setiap unit pelajaran setidaknya me- 
nampilkan sepotong stimulus materi --dapat berupa kisah, dialog, artikel surat kabar, dll-- yang dipilih untuk mengilustrasikan aspek penting dari pemikiran atau argumentasi politik tertentu. Contoh dari model ini misalnya wacana mengenai dilema kewaspadaan, kekuatan pasar, rasisme, sifat dan atribut politik yang diperlukan dan diinginkan dari seorang politisi, termasuk esensi dan penggunaan ideologi. Pembelajaran aktif dan latihan pemecahan masalah dipilih agar memungkinkan siswa terlibat dengan ide-ide yang tersirat dalam stimulus pembelajaran dalam diskusi di berbagai tingkat kecanggihan intelektual. Pertanyaan diajukan dalam setiap unit yang dipilih untuk mendorong refleksi dari perdebatan, sehingga memungkinkan untuk mengidentifikasi konsep-konsep politik dan bentuk-bentuk argumen yang terlibat.

Sudah barang tentu yang tidak boleh ketinggalan di sini adalah evaluasi dari keseluruhan proses yang dilakukan. Evaluasi penting untuk memastikan bahwa desian yang disiapkan benar benar menjadi kenyataan, yaitu terwujudnya siswa sebagai pribadi yang melek politik, terampil dalam berinteraksi dengan entitas sosial yang beragam dan dapat berpartisipasi secara benar sebagai warga negara yang bertanggung jawab. Dua hal penting yang perlu mendapatkan perhatian dalam evaluasi adalah gaya mengajar seperti apa yang dapat digunakan untuk mempromosikan 'wacana publik' sebagai fitur utama dari literasi politik dan apa saja jenis tanggapan siswa, yang berhubungan dengan wacana publik, yang muncul dari gaya mengajar tersebut. Tanpa evalusasi yang memadai dikhawatirkan pendidikan politik lebih sekolah dapat berubah menjadi indoktrinasi politik partisan, yang justru bertentangan dengan semangat demokrasi yang berkeadaban.

\section{Agama}

Agama dapat menjadi sebuah ideologi yang akan mempengaruhi pandangan seseorang tentang banyak hal. Hal ini karena agama seringkali berfungsi sebagai basis bagi seseorang 
ketika memutuskan hal-hal penting. Seberapa besar agama dalam mempengaruhi sebuah pandangan dan kecenderungan politik seseorang? Menurut Covert dan Wesburn (2017) Agama memiliki peran khusus dalam sebuah pemilihan presiden. Pada prinsipnya, pandangan politik tidak akan bertentangan dengan pemahaman keagamaan seseorang. Maka seseorang yang telah memiliki pandangan agama yang kuat, secara bijaksana akan memandang politik sebagaimana yang diajarkan oleh agama yang dianut. Tokoh-tokoh agama oleh karenanya memegang peran yang sangat strategis dalam melakukan transformasi nilai-nilai demokrasi dan kesadaran politik kepada jemaatnya masing-masing.

Dalam realitas politik, warga sering memiliki perasaan campur aduk tentang kesesuaian antara apa yang dibahas oleh sang tokoh, apakah itu sebagai pendapat politik pribadi, sesuai dengan keberpihakannya masing-masing, ataukah itu sebagai pandangan resmi otoritas agama. Masih menjadi perdebatan publik hingga kini mengenai apa sebenarnya peran tokokh agama dalam pendidikan politik warga. Apakah mereka boleh mempergunakan mimbar-mimbar keagamaan sebagai media untuk sosialisasi politik? Apakah sosialisasi politik di sini termasuk melakukan kegiatan kampanye politik dan ikut campur tangan dalam pemilihan pejabat publik? Jika jawabannya adalah ya, maka ini berarti tokoh agama ditempatkan sebagai agen sosialisasi politik. Di lapangan, organisasi-organisasi keagamaan memang mengambil posisi publik dalam isu-isu sosial yang urgen, seperti dalam penyusunan perundang-undangan dan pemilihan pejabat pusat dan daerah.

Salah satu pengaruh sosial paling mendasar dari organisasi keagamaan di banyak negara adalah memberikan legitimasi pada sistem politik. Pada tahun-tahun awal perkembangan, anak-anak cenderung melihat orang tua sebagai sumber aturan sosial yang tidak dapat diubah. Pada titik tertentu, pandangan ini memberi jalan kepada kesadaran bahwa orang tua juga tunduk pada aturan yang tidak mereka buat sendiri. Sumber-sumber aturan semacam itu secara samar dipahami sebagai agama dan, pada 
tingkat yang lebih rendah, politik. Faktanya, banyak anak mengacaukan otoritas agama dan politik. Misalnya, Anak-anak sering membahas presiden sebagai "orang terbaik di Dunia", yang memiliki kekuasaan mutlak atas bangsa, dan sebagai pribadi yang tertarik pada kebutuhan setiap individu warga negara.

Pengalaman keagamaan setiap warga negara bersama tokoh agama dan anggota jamaah lainnya memberikan praktek langsung mengenai prosedur berdemokrasi. Partisipasi aktif dalam kehidupan sebuah masjid, gereja, pure, wihara dapat mengarah pada perolehan keterampilan yang diperlukan untuk partisipasi politik yang efektif. Keahlian seperti itu termasuk bagaimana mengatur dan menjalankan pertemuan, menulis surat, dan mendebat masalah. Pada gilirannya, mempraktekkan keterampilan seperti itu dapat mengantarkan pelakunya pada kesadaran akan pentingnya partisipasi organisasi dan mempromosikan nilai-nilai demokrasi, termasuk memberi perhatian lebih pada kebaikan publik, kerja sama, menghormati orang lain, menghormati aturan hukum dan kemauan untuk berpartisipasi dalam kehidupan publik.

Menanamkan kepercayaan tentang pentingnya membantu menyejahterakan kehidupan orang lain mempengaruhi partisipasi politik. Sebenarnyalah beberapa kategori keyakinan agama telah ditemukan mempengaruhi partisipasi politik warga negara. Keyakinan agama dapat dibedakan menjadi mikro dan makro. Yang pertama termasuk keyakinan yang bersifat pribadi dan fokus pada kepentingan individu. Termasuk di sini soal doa, keuangan pribadi, atau hubungan mereka dengan Tuhan. Keyakinan makro melibatkan masalah yang lebih umum. Contohnya termasuk keyakinan akan pentingnya mencari keadilan sosialekonomi dan berdoa untuk orang yang tidak dikenal secara pribadi. Temuan menunjukkan bahwa keyakinan mikro tidak begitu berpengaruh pada partisipasi politik nasional, sementara kepercayaan makro lebih kuat pengaruhnya (Davies \& Hogarth 2004).

Pemahaman keagamaan mempengaruhi intoleransi politik 
dalam arah yang tidak menentu. Tidak terdapat hubungan langsung antara doktrin agama dengan intoleransi politik. Yang sering menjadi persoalan dalam hal ini adalah penyalahgunaan doktrin-doktrin agama untuk kepentingan-kepentingan politik jangka pendek. Ayat-ayat kitab suci terkadang dipelintir sedemikian rupa pemaknaannya, hanya untuk dijadikan alat kampanye tokoh-tokoh tertentu. Atau jargon keagamaan dipakai sebagai senjata untuk menghantam lawan politik yang hendak di kalahkan. Agama yang seharusnya dapat berperan sebagai alat pemersatu bangsa, di tangan orang yang tidak bertanggung jawan dapat dengan sangat menyedihkan dibalik menjadi faktor yang dapat memicu konflik sosial yang berdarah-darah.

Agama dapat pula perberan sebagai status kelompok. Kelompok-kelompok agama diberi sejumlah kehormatan dan prestise sosial yang berbeda. Misalnya, di Amerika Serikat, umat Katolik menikmati status sosial yang lebih tinggi daripada orang Yahudi. Hal ini terlepas dari fakta bahwa orang Yahudi pada umumnya cenderung bekerja di pekerjaan yang lebih bergengsi, memiliki pendapatan dan tingkat pendidikan yang lebih tinggi daripada orang Katolik. Oleh karena itu, kelompok-kelompok agama merupakan kelompok status yang posisi relatifnya tidak sepenuhnya ditentukan oleh komposisi kelas keanggotaan kelompoknya. Stratifikasi sosial kelompok agama seperti yang terjadi di Amerika memiliki akar sejarah di masa lalu. Kenyataan demikian terjadi pula di negara-negara lain. Di Malaysia misalnya, melayu muslim menjadi warga negara "kelas satu".

\section{Asosiasi Profesi dan Lembaga Swadaya Masyarakat}

Di banyak negara, termasuk di negara adi daya seperti Amerika Serikat, hampIr tidak ada pekerjaan yang benar-benar kebal dari pengaruh keputusan politik. Persyaratan perizinan dan sertifikasi, undang-undang upah minimum, undang-undang pekerja anak, undang-undang yang mengatur jam kerja dan lain sebagainya menggambarkan kebijakan publik yang mempengaruhi kondisi objektif pekerjaan. Keputusan pemerintah untuk 
mendanai atau menghentikan pendanaan berbagai program akan sangat mempengaruhi bekerja atau menganggurnya jutaan orang. Dengan kata lain, di banyak tempat, pemerintah, di semua tingkatan, adalah pemberi kerja utama.

Mereka yang percaya bahwa kelompok pekerjaan yang ditekuni dipengaruhi oleh dinamika politik praktis lebih cenderung untuk berpartisipasi dalam politik bila dibandingkan dengan kelompok lain yang tidak memiliki pandangan demikian. Orang-orang seperti itu bisa jadi berada dalam pekerjaan yang mengharuskannya sering bersentuhan dengan institusi-institusi politik yang terkait. Suatu jenis pekerjaan yang selalu membutuhkan informasi yang relevan secara politik dan keterampilan intelektual dan sosial yang tinggi. Keahlian seperti itu, termasuk kemampuan untuk memahami, menafsirkan, dan secara efektif mengkomunikasikan informasi sosial, ekonomi, dan politik; kemampuan untuk merumuskan dan mengekspresikan tujuantujuan politik yang diinginkan merupakan kesiapan penting yang diperlukan dalam memasuki dunia politik.

Secara umum, pekerjaan berstatus tinggi seperti sebagian besar profesi dan posisi eksekutif dan manajerial membutuhkan pendidikan dan melibatkan pelaksanaan tugas yang memungkinkan memiliki keahlian tinggi. Sementara beberapa pekerjaan manual dan klerikal, di sisi lain, tidak memerlukan persyaratan pendidikan dan tidak pula menyediakan pengalaman yang terkait keterampilan sosial tinggi. Ini sebagian dapat menjelaskan fakta mengapa orang-orang dengan status pekerjaan yang lebih tinggi cenderung lebih berpartisipasi dalam politik. Tempat kerja adalah lingkungan yang menawarkan kesempatan lebih besar kepada subjek untuk melakukan percakapan dengan orang-orang yang memiliki perspektif politik yang berbeda dari keluarga, sekolah, atau insitusi keagamaan. Dengan demikian dapat dipahami mengapa aktivis asosiasi profesi dan LSM lebih tinggi partisipasi politiknya dibandingkan yang lain. 


\section{Media}

Perkembangan teknologi di era globalisasi telah menghantarkan pada era dimana segala informasi tersebar begitu cepat dan serentak. Hal ini memiliki sisi positif sekaligus negatif bagi perkembangan sosialisasi politik. Kini masyarakat tidak perlu susah payah dalam mengenali calon yang akan menjadi pilihannya. Media menyediakan segala informasi mengenai orangtua, guru, kepercayaan, pengalaman kerja dan lain-lain yang coba dikonstruksikan sebagai sebuah informasi yang ingin disampaikan seseorang kepada khalayak. Media juga menjadi upaya promotif yang strategis. Namun pada sisi lain, apakah di era informasi dengan semakin banyaknya hoax dapat mempengaruhi perilaku politik warga? Meskipun jika dicerna dengn nalar kritis hal seperti ini gtentu tidak dapat mempengaruhi seseorang, akan tapi pada praktiknya berita bohong tetap dapat mempengaruhi masyarakat secara luas. Setidaknya pengaruh yang ditimbulkan adalah semakin familiarnya warga terhadap nama orang-orang yang terus diberitakan.

Sistem pemrosesan informasi politik merupakan sebuah strategi yang biasanya digunakan oleh pelaku politik untuk membangun kepercayaan ataupun untuk menumbuhkan keberpihakan kepada pihak tertentu. Proses komunikasi politik seringkali mempengaruhi bagaimana pemberitaan dan iklan politik. Media sosial kini juga terbukti semakin sering digunakan sebagai alat untuk mempersuasi pemilih. Pengalaman negaranegara barat, pers telah menjadi kekuatan besar, bahkan dalam beberapa hal terasa lebih kuat dari legislatif, eksekutif, dan peradilan. Dengan jaringan media global, media internasional dapat menyiarkan berita dan opini ke seluruh dunia. Media sekarang memang terlihat memiliki kekuatan dan pengaruh yang belum pernah terjadi sebelumnya. Peningkatan jangkauan global, kecepatan dan kapasitas untuk mengirimkan pesan mengikuti kemajuan luar biasa dalam teknologi komunikasi. Ketersediaan peralatan satelit portabel memungkinkan liputan instan dari mana saja. 
Dan karena kekerasan adalah 'baik untuk bisnis media', karena menyajikan peristiwa dramatis, kejadian berbahaya, tak terduga dan penuh emosi, maka kekerasan merupakan salah satu topik yang mendapat perhatian rutin. Konsekuensi dari liputan media tentang kekerasan politik dalam beberapa tahun terakhir telah menjadi keprihatinan bahwa media telah meningkatkan kemampuannya dalam mempengaruhi pembuatan kebijakan negara. Dengan demikian, istilah efek media telah muncul untuk merujuk pada dugaan pengaruh liputan berita real-time pada proses pembuatan kebijakan politik. Namun, untuk mengklaim bahwa kebijakan politik sekarang dibuat sebagai tanggapan terhadap 'impuls dan gambar' kemungkinan besar tidak akurat. Adanya atau tidak adanya perhatian media bukanlah variabel kunci dalam menentukan pengaruh media. Di sisi kebijakan, hanya pada saat-saat terjadi kepanikan kebijakan, maka media berita dapat memiliki pengaruh. Di sisi media, ketika media membingkai laporan dengan cara kritis dari kebijakan resmi pemerintah, dan dengan cara empati terhadap korban yang menderita dari konflik tertentu, maka media berpotensi dapat memberikan pengaruh pada pembuatan kebijakan.

Krisis kepercayaan terhadap institusi dan organisasi politik; tuntutan untuk pemimpin baru yang tidak hanya dapat memaksakan keputusan tetapi juga untuk menarik, menginspirasi, dan membujuk; dan meningkatnya peran proses bottom-up dalam partisipasi adalah semua fenomena yang mengarah ke arah integrasi yang lebih baik antara interaksi horizontal di antara warga dan interaksi hierarkis antara pemimpin dan pengikut. Pertanyaan utamanya kemudian adalah, bagaimana perkembangan yang sedang berlangsung dalam komunikasi politik dan dalam sistem media mendorong pergeseran ini dari model kepemimpinan tradisional ke yang lebih fleksibel, terdefinisi, dan transformasional? Dan apa konsekuensi dari proses perubahan seperti itu bagi perempuan yang mengejar jabatan politik yang lebih tinggi? Tren global saat ini ditakdirkan untuk meningkatkan posisi wanita. Meskipun persepsi maskulin orangorang terhadap kepemimpinan telah menempatkan pemimpin 
perempuan pada posisi yang kurang menguntungkan, persepsi ini berubah dengan cara yang semakin menguntungkan wanita. Persaingan global, pertumbuhan teknologi, peningkatan tenaga kerja dan keragaman pelanggan, dan percepatan perubahan sosial semuanya menempatkan tekanan yang semakin meningkat pada organisasi untuk menemukan pendekatan baru dan kreatif terhadap kepemimpinan dan manajemen.

Tetapi peremajaan konkret hubungan antara pemimpin dan warga negara dan dorongan untuk kepemimpinan perempuan dapat datang terutama dari Internet. Kemajuan teknologi baru ini terbukti menjadi alat yang kuat untuk mobilisasi politik: kelompok-kelompok kepentingan dan gerakan sosial menggunakannya sebagai sarana untuk menekan elite politik. Secara khusus, blogging misalnya telah mendemokrasikan akses dengan teknik yang diperlukan untuk membuat perubahan politik melalui pembuatan konten dan ditakdirkan untuk menjadi sarana mobilisasi yang baik dengan dimediasi-Internet. Singkat kata, menurunnya partisipasi politik tradisional dan hilangnya kepercayaan pada elit politik menghasilkan bentuk-bentuk baru aktivisme sipil di mana web dapat menjadi ruang kosong, yang terbuka bagi warga untuk mengekspresikan diri dengan cara yang konstruktif dan demokratis.

Peran media yang sedemikian mengesankan semestinya dapat dipergunakan dengan bijak untuk mempengaruhi partisipasi politik warga. Secara khusus, ke depan harus dipertimbangkan bahwa perkembangan teknologi komunikasi yang cepat telah membawa perubahan dalam komunikasi politik. Semua ini memiliki implikasi penting bagi berfungsinya sistem politik dan kualitas demokrasi. Dalam jangka panjang perlu dieksplorasi lebih jauh bagimana interaksi antara politik dan budaya populer dan peran internet dalam membentuk kembali kepemimpinan yang lebih berkualitas.

\section{Penutup}

Pendidikan politik di era disrupsi berbeda dengan era 
sebelumnya, yang bersifat monolitik, satu arah dan bersifat indoktrinatif. Kini pendidikan politik lebih terbuka, partisipatif dan melibatkan semua pemangku kepentingan. Lewat keluarga nilai-nilai dasar berdemokrasi mulai disemaikan. Sekolah dengan pendekatan pendidikannya yang baru dapat memberikan penguatan dengan aneka diskusi wacana publik, memperdebatkan isu-isu politik kontemporer. Agama dan interaksi jamaah di tempat-tempat ibadah memberikan bekal yang kokoh dari ajaran agama dan basis keterampilan sosial yang diperlukan dalam partisipasi politik. Melaui tempat kerja, warga juga mendapatkan tambahan literasi politik. Identifikasi individu dalam kelompok sosial sedikit banyak juga akan menentukan pilihan politik seseorang. Pada akhirnya, di era dengan perkembangan media komunikasi seperti sekarang ini, pesan-pesan politik dapat dengan lebih cepat sampai kepada khalayak. Literasi media dapat meningkatkan partisipasi politik secara lebih signifikan. 


\section{DAFTAR PUSTAKA}

Bakri, A. F., et al. 2012. Literasi Politik dan Konsolidasi Demokrasi. Jakarta: Churia Press.

Davies, I. \& S. Hogarth. 2004. Political Literacy: Issues for Teachers and Learners. Dalam Demaine, J. Citizenship and Political Education Today. New York: Palgrave MacMillan.

Gimpel, J. G., J. C. Lay, J. E. Schuknecht. 2003. Cultivating Democracy, Civic Environments and Political Sociliization in America. Washington D.C: The Bookings Institution.

Habashi, J. 2017. Political Socialization of Youth, A Palestianian Case Study. New York: Palgrave MacMillan.

Macintyre, J. 1993. Political Socialization of Youth in The Soviet Union: Its Theory, Use, and Result. USA: Naval Postgraduate School, Monterey, California.

Roots, J.. 1999. The Politics of Visual Language. Canada: Carleton University Press.

Wasburn, Ph. C., T. J. A. Covert. 2017. Making Citizen. New York: Palgrave Macmillan.

Yu, M. 2017. Instrumental Autonomy Political and Citizenship Identity. Singapore: Springer Nature. 